The "Modus Operandi" of Esmarch's Elastic Bandage in the Treatment of Aneurism.

Mr. A. Pearce Govld, Assistant-Surgeon to Westminster Hospital, London, read a paper on this subject, of which the following is a sumulary, at the late London Congress :-

1. It is first pointed out that while other methods of treatment-Ligature, Instrumental and Digital Compression, Flexion-lessen or entircly stop the flow of blood through part or parts of the main blood-channel, they do not interfere with the blood-current in secondary vesscls, or control the anastomotic circulation. Esmarelı's Elastie Bandage, on the other hand, when firmly applied, stops the circulation in all the vessels of the part.

2. It is next shown that the eure of an aneurism is bronght about by the obliteration of its cavity, either by fibrin, or by clotted blood, and subsequent organization of the same.

3. The conditions leading to the deposit of fibrin are cliscussed, the main condition being shown to be contaet of moving blood witl foreign borlies, white in eonsideration of the mode of formation of bloorlclot in the living bodly shows it to be especially dependent upon the eirenlation of destruetive or eoagulating substanees, and the contact of foreign or unhealthy matter with blood in a state of rest.

4. The vital properties of fibrin and bloodelot are next compared, and particular stress is laid upon the facts that fibrin is very stable, and resists the processes of organization and absorption, while bloodelot is very unstable, and may be. readily absorbed or organized; the conditions determining these ehinges are referred to.

5. From these premises it is deduced that Esmarch's Bandage, so applied as to stop all eirculation, does not eanse a deposit of fibrin, but unay eause a eoagulation of the blood en masse.

6. The faet that this coagulum may be absorbed, broken down, or organized, the eonditions leading to these chlangex, and their results, are then stated.

7. From these eonsiderations certuin deductions are drawn as to the cases of aneurism in which this method of treatment is likely to give the best results, ancl to those in which it is likely to fail. The value of preparatory treaturent is insistcd upon.

'The pathological and elinical evidcuce bearing upon and supporting these views was detailed by Mr. Gould.

\title{
Treatment of Injuries of Bloodvessels in the Field.
}

Dr. F. Esmancer, Professor of Surgery in the University of Kiel, read an elaborate paper on this subject at the London Congress, from which the following is an abstract:-

1. The indications in the trcatment of injuries of the larger arterial trunks, and of traumatic hemorrlage, have been considerably simplified by the introduction of "antiscptics," and of Esmarch's bandage.

2. The practice, fornerly in use, of ligaturing arteries above the wound is uncertain, and ought, therefore, to be cutirely discarded.

3. The applieation of styptics is equally objectionable, not only beeanse of their uneertain action, but becausc they foul a wound, and interfere with its healing.

4. In all cases of hemorrhage, threatening life, the wounded vessel must, if possible, be cxposed at the seat of injury, and ligatured above and below this point, either with catgut or antisepticised silk.

5. This operation nust be carried out under the most rigid antiseptic precauNo. CLXIV._Ocr. 1881. 
tions; if on the extremities, an Esmarch's bandage must be applied. As it is necessary in all such eases to disinfect the wound, even to its innermost recesses, the disinfection and the operation ean be done at the same time.

6. The most effectual method to render such operations easy, rapid, and thorough, is to make a free incision parallel with the axis of the limb. When life is at stake, it matters little whether such an incision is one inch or one foot in length, provided that the hemorrhige is arrested, and that the wound is kept sweet; the large wound hcals just as well as the sinall onc.

7. After freely incising the skin, the operator inserts his left index finger deep into the wound, and, with a button-pointed bistoury, opens up, just as freely, the deeper layers of connective tissue, fascive, and muscles, while an assistant now separates the parts with retractors.

8. The blook-clot, which is generally found to fill the wound, and to have infiltrated the surrounding eellular tissue, is now rapidly turned out, either with the fingers, or sponges, or raspatories, partly because it hides everything, and partly to aroid subsequent decomposition. It is only under these circumstances that any operation can be carried out with anything like exactitude.

9. As soon as this is done, the operator feels with lis finger for the vascular and nerve trunks, and endeavours, with the aid of a clean sponge, to learn the exact nature of the injury.

10. When the large veins are empty and collapsed, it is sometimes difficult to distinguish them from strands of eonneetive tissue. On this account it is advisable to provide a little reserve of blood, which may be done in this manner: For the aum, a cord might be fastened round the wrist below the wound, before the elastic (Esmareh) bandage was applied; then, on looscning this and raising the arm, the blood shut up in the hand would, if the vein was injured, flow into the wound, and would so make it manifest.

11. As soon as the injured spot of the artery or rein has been laid bare, so that its full extent can be clearly seen, the vessel must be isolaterl and then seeurely ligatureel, either with cutgut or carbolized silk, above and below the injury. If the continuity of the ressel lias not alroady becn destroyed by the injury, the vessel must he eut between the two ligatures. The operator should convince himself that no lateral or deep branehes are given off to the injured part of the trunk. Should any small branches be found they ought to be carefully isolated, ligatured, and then separaterl from the parent trunk.

12. The Lsmarch bandage should now be renored, and all bleeding vessels carefilly tied, the limbs being raised, as after amputations.

13. Slowld any nerve trunks or tendons have been divided, their extremities must be sought for and sewn together either with fine catgut or earbolized silk.

14. Any foreign bodies (bnllets, bits of boue, or fragments of clothes) which nay be found should be removed.

15. The whole wound must now be thoronghly disinfected, either by irrigation, ur rubbing in chloride of zinc, or strong earbolie solution, taking care that the Huid gets into every little recess.

16. After counter openings have been made in suitable places, and drainage tubes put in, the wound must be elosed with antiseptic sutures, and finally the antiseptic compressive-dressing applied.

17. This operation ean hardly be earried out on the battle-ficld, or in a first field-hospital, because it requires both time and eare, and because the necessary antiseptic precautions are only to be had in a thoroughly well-organized lazaretto (hospital).

18. The elastie bandage can alone be recommended for the provisional arrest of liemorrhage on the battle-field. 
19. The use of styptics is very objectionable; all such remedies ought thercfore to be banished from the surgeon's field-case.

20. The application of tourniquets, formerly so much in vogue, is likewise to be deprecated as uncertain and dangerous, not only because their application requires preeise anatomical knowledge, but, and chiefly bccansc, however accuratcly the pad may be adjusted, it is almost sure to slip aside during transport; the binder then interferes not only with arterial but also with the venous circulation. As at nccessary eonsequenee cither the hemorrlinge recurs, or, if an external wound is closed, dangerous blood infiltration of the limb takes place.

21. An effectual and permanent compression of the vessels can be secured by means of an elastic tube, applied, while cxtended, two or thrce times round the limb. The soft structures are in this way compressed on all sides, and the circulation is entirely arrested.

22. As this compression is efficient to whichever part of the limb it is applied, no anatomieal knowledge is necessary. It is in no way interfered with by transport, and it cannot slip if the extremities of the tube are carefully fastened.

23. On this account all tourniquets should be renoved from the armamentaria of field hospitals, and be replaced by clastic tubes.

24. Every wounded man, on whom hemorrhage has been provisionally arrested by an elastie tube, ought of course to be removed as rapidly as possible to a lospital, in order that the compression may be removed, and the ligature of the wounded vessel inumediately undertaken.

25. It is very advantageous, before putting on the elastic tube, to apply a bandage to the limb while in a raised position. If the bone is fraetured, a fixative bandage of some kind ought to be applied for transport.

\section{OPHTHALMOLOGY AND OTOLOGY. \\ Operations to be Enplnyed in the Various Forms of Glaucoma.}

- Dr. Dr Wreken, of Paris, read a paper on this subject at the London Congress, of which the following is an abstract:-

The most enthusiastic supporters of iridectomy in glaucoma must admit that there are cases in which this opcration is ineffeetive, or even injurious. This armission, made even by Von Gracfe hinuself, justifies the zeal with which new methods of operative treatment have been songht after, aided by the use of myotics.

Sclerotomy, which lats now definitely established for itself a position in eyc surgery, has filled up the gap left by the insuffieiency of the iridectomy operation.

It is inportant to every observer to know what part iridectomy and sclerotomy play in the curc of glinucoma, in order to give in each case the greatest possible chance of permanent curc.

Sclerotomy will be eugcrly resorted to in those cases in which iridectomy is known to be dangerous-viz, in glincoma hæmorrhagicum, or in glaucoma congenitale, or glaucoma infantile, otherwise known as buplitlalmic liydrophthalmia. Also where iridectomy is unreliable-that is to say, according to Von Graefe's own admission, in simple chronic glancoma, with the absence of any inflammatory symptoms. Also in those cases where the visual field has contracted ncarly to the point of fixation, it is unsafe to remove any iris. And prolonged expcrience satisfies the author still more that the scleral incision alone is the best, most complete, and safest in simple ehronic glaucoma.

Shall we, then, say that all glancomas, not amenable to iridectomy, are eurable 